\title{
EPIDEMIOLOGICAL PROFILE OF HEPATITIS C VIRUS INFECTION IN PATIENTS FROM WEST REGION OF MINAS GERAIS STATE, BRAZIL
}

\author{
PERFIL EPIDEMIOLÓGICO DA INFECÇÃO PELO VÍRUS DA HEPATITE C EM \\ PACIENTES DA REGIÃO OESTE DE MINAS GERAIS, BRASIL
}

\begin{abstract}
Lívia Melo VILLAR ${ }^{1}$; Neila Paula de SOUZA ${ }^{2}$; Suzely Adas Saliba MOIMAZ ${ }^{3}$; Artênio José Isper GARBIN ${ }^{4}$; Aércio Sebastião BORGES ${ }^{5}$; Cléa Adas Saliba GARBIN ${ }^{6}$

1. Technologist, Viral Hepatitis Laboratory, Oswaldo Cruz Institute - FIOCRUZ, Rio de Janeiro, RJ, Brazil; 2. Master Degree and PhD Student, Preventive and Social Dentistry Post-graduation Program, Universidade Estadual Paulista - Unesp, Araçatuba, SP, Brazil, neilapsouza@hotmail.com; 3. Full Professor and coordinator, Preventive and Social Dentistry Post-graduation Program, Universidade Estadual Paulista - Unesp, Araçatuba, SP, Brazil; 4. Adjunct Professor, Preventive and Social Dentistry Post-graduation Program, Univ. Estadual Paulista - Unesp, Araçatuba, SP, Brazil; 5 Assistent Professor, Institute of Biomedical Sciences, Federal University of Uberlândia, Uberlândia, MG, Brazil; Adjunct Professor and vice-coordinator, Preventive and Social Dentistry Post-graduation Program, Universidade Estadual Paulista - Unesp, Araçatuba, SP, Brazil
\end{abstract}

\begin{abstract}
Hepatitis C virus (HCV) is a serious public health problem and is the leading cause of liver transplantation due to cirrhosis and hepatocellular carcinoma. In Brazil, it is estimated that there are approximately 2 to 3 million HCV chronic carriers. Few data regarding HCV infection are available in West region of Minas Gerais State. Due to the absence of an effective vaccine against this important human pathogen and the high costs of antiviral treatment, it is important to conduct epidemiological studies with the purpose of carry out the planning and implementation of measures to prevent hepatitis $\mathrm{C}$ in different populations. Therefore, the aim of this study is to describe the epidemiological aspects of $\mathrm{HCV}$ patients from West region of Minas Gerais State, Brazil. Sociodemographic data and risk factors for HCV infection were determined from $74 \mathrm{HCV}$ patients from Uberlândia city (Minas Gerais State). Reactive anti-HCV sera samples were submitted to HCV RNA and genotype detection. Most of individuals were male (63.5\%) with mean age of 51 years and presenting low socioeconomic status. HCV genotype was determined among 40 samples and the frequencies were: genotype $2(45 \%), 1(37.5 \%)$ and $3(17.5 \%)$. Hepatitis $\mathrm{C}$ virus $(\mathrm{HCV})$ infection was common among male and low socioeconomic status individuals.
\end{abstract}

KEYWORDS: Hepatitis C. Epidemiology. Public Health.

Hepatitis $\mathrm{C}$ virus (HCV) is a major responsible for chronic liver disease, and it is estimated that 123 to 170 million people are infected worldwide (LAVANCHY, 2011). HCV belongs to Hepacivirus genus at Flaviviridae family and presenting a single-stranded RNA genome and 7 genotypes (SMITH et al., 2014). HCV genotypes are predictive of treatment response with interferon and ribavirin and high rates of sustained viral response (SVR) are associated to genotypes 2 and 3. However, genotype 1 is the most prevalent all over the world (LAVANCHY, 2011; PEREIRA et al., 2013).

The incidence of hepatitis $\mathrm{C}$ varies widely throughout the world in different population subgroups and high prevalence rates are observed among illicit drug users and individuals who received transfusion of blood products before 1994 (LAVANCHY, 2011). In Brazil, a prevalence of HCV equal to $1.38 \%$ in capitals and major cities indicates intermediate levels of endemicity (BRASIL, 2011; KRETZER et al., 2014; PEREIRA et al., 2013).

Few data regarding $\mathrm{HCV}$ infection are available in Minas Gerais State, especially at West
Region of State known as Triangulo Mineiro who is the second most populous region of this State. In the absence of an effective vaccine and high costs of antiviral treatment, it is important to conduct epidemiological studies for planning and implementing measures to prevent hepatitis $\mathrm{C}$ in different populations. Therefore, the aim of this study is to describe epidemiological aspects of $\mathrm{HCV}$ patients from West region of Minas Gerais State, Brazil.

A convenience sample of $\mathrm{HCV}$ patients referred to Chronic Liver Diseases Ambulatory from Clinics Hospital of the Federal University of Uberlandia City (Minas Gerais State) was included in this study. Sample size was determined based on the number of chronic hepatitis $\mathrm{C}$ cases reported in SINAN Net (Notifiable Diseases Information System) between the years 2006 to 2011 in Uberlandia (258 confirmed cases of hepatitis $C$ with an annual average of 42 cases). As results, $74 \mathrm{HCV}$ infected individuals of both genders were invited to participate in this study from February to September 2013.

The study was approved by Local Ethics in Human Research Committee and all individuals 
signed an informed consent. All volunteers were informed about the objectives and procedures of the study. Inclusion criteria were: age equal or higher than 18 years and positive anti-HCV and positive HCV RNA for more than 6 months. Exclusion criteria were the refusal to sign the informed consent, the presence of cognitive difficulties, HBV or HIV coinfection and haemodialysis treatment.

Sociodemographic data (age, sex, race/ethnicity, marital status, occupation and family income) and risk factors for $\mathrm{HCV}$ acquisition (sexual orientation, number of sexual partners in the last 3 months and condom use at the last intercourse) were obtained using a standardized questionnaire.

Blood samples $(5 \mathrm{~mL})$ were obtained from each individual by venipuncture using BD Vacutainer ${ }^{\circledR}$ SST ${ }^{\circledR}$ II Advance ${ }^{\circledR}$ tubes. Sera was obtained by centrifugation and subjected to the immunosorbent assay (ELISA) for anti-HCV detection (Hepatitis $\mathrm{C}$ anti-HCV Wiener ${ }^{\circledR}$ lab) following the manufacturer's instructions. Reactive anti-HCV samples were subjected to the HCV RNA detection using COBAS $®$ AMPLICOR Hepatitis C Virus (HCV) Test, version 2.0 (Roche, USA). HCV RNA positive sera were genotyped using Abbott RealTime HCV Genotype II (Abbott, USA) according to the manufacturer's instructions.

The information collected was stored in a data bank using the Excel 2003 software (Microsoft Office). Data are expressed by means of descriptive statistical analysis using the EpiInfo 3.4.1 software. Out of the $74 \mathrm{HCV}$ patients included in this study, 47 were male $(63.5 \%)$ and mean age of the population was 51.6 years $( \pm 11.5)$. Most of individuals were Caucasian $(67.6 \% ; \mathrm{n}=50)$, married $(52.7 \% ; n=39)$ lived with a spouse $(33.8 \% ; n=25)$, had up to 8 years of schooling $(56.7 \% ; n=42)$, employed (43.3\%; $\mathrm{n}=32)$ and receiving until US\$620.00 monthly income $(52.7 \% ; n=39)$ (Table 1).

Table 1. Sociodemographic and risk behavior data from hepatitis $\mathrm{C}$ virus infected individuals referred to Clinics Hospital from Federal University of Uberlandia (Minas Gerais State) in year 2013 (n=74).

\begin{tabular}{|c|c|c|}
\hline Variables & $\mathrm{n}$ & $\%$ \\
\hline \multicolumn{3}{|l|}{ Gender } \\
\hline Female & 27 & 36.5 \\
\hline Male & 47 & 63.5 \\
\hline \multicolumn{3}{|l|}{ Race/Ethnicity } \\
\hline Caucasian & $\mathbf{5 0}$ & 67.6 \\
\hline Other race or ethnicity & 24 & 32.4 \\
\hline \multicolumn{3}{|l|}{ Age (years) } \\
\hline$<40$ & 14 & 18.9 \\
\hline 41-50 & 21 & 28.4 \\
\hline $51-60$ & 21 & 28.4 \\
\hline$>60$ & 18 & 24.3 \\
\hline \multicolumn{3}{|l|}{ Occupation } \\
\hline Retired & 23 & 31.1 \\
\hline Unemployed & 8 & 10.8 \\
\hline Housewife & 6 & 8.1 \\
\hline Employee & 32 & 43.3 \\
\hline Medical license & 1 & 1.3 \\
\hline Prisoner & 4 & 5.4 \\
\hline \multicolumn{3}{|l|}{ Family income } \\
\hline$<\mathrm{US} \$ \mathbf{3 0 8}$ & 6 & 8.1 \\
\hline US\$308 to US\$620 & 33 & 44.6 \\
\hline US\$621 to US\$924 & 24 & 32.4 \\
\hline >US\$924 & 10 & 13.5 \\
\hline Did not answer & 1 & 1.4 \\
\hline
\end{tabular}


Years of schooling

\begin{tabular}{lrr}
4 years & 22 & 29.7 \\
5 to 8 years & 20 & 27.0 \\
9 to 10 years & 11 & 14.9 \\
more than 11 years & 21 & 28.4 \\
Heterosexual & & \\
Yes & 71 & 95.9 \\
No & 3 & 4.1 \\
Number of sexual partners & & \\
$\leq 1$ & 54 & 73.0 \\
$\geq 2$ & 20 & 27.0 \\
Condom Usage in the last intercourse & & \\
Yes & 9 & 12.2 \\
No & 65 & 87.8 \\
\hline
\end{tabular}

Regarding the sexual orientation, most of individuals declared to be heterosexual (96\%, $\mathrm{n}=71$ ), reported having one sexual partner during the last three months $(74 \%, \mathrm{n}=54)$ and did not use condom at last intercourse $(87.8 \%, \mathrm{n}=65)$ (Table 1$)$.

HCV RNA was detected in all seropositive samples for anti-HCV $(n=74)$ and only individuals that met inclusion criteria for antiviral treatment was submitted to HCV genotype $(\mathrm{n}=40)$. Samples were submitted to HCV genotyping and their frequencies were: 18 samples from genotype 2, 15 samples from genotype 1 and 7 samples from genotype 3 . Regarding $\mathrm{HCV}$ subtypes, $37.5 \%$ belonged to subtype 1a (15/40), $42.5 \%$ were $2 \mathrm{a}(17 / 40), 2.5 \%$ were $2 b(1 / 40)$ and $17.5 \%$ (7/40) were subtype $3 a$.

Chronic Liver Diseases Ambulatory from Clinics Hospital of the Federal University of Uberlandia City (Minas Gerais State) is a Public Health Reference Center for diagnosis and treatment of viral hepatitis in Minas Gerais State. Uberlandia is the most populous city of Triângulo Mineiro Region with about 650000 inhabitants and it is an important regional health center for other neighboring towns.

This study showed that most of $\mathrm{HCV}$ individuals from this center were male, Caucasian and aged between 41 and 60 years. Similar results were observed in Uberaba, a neighboring city and in an epidemiological survey conducted in major Brazilian cities, where individuals aged 20 to 69 years old $(1.63 \%)$ and males $(1.83 \%)$ presented high anti-HCV prevalence in the Southeast region of the country (GARCIA et al., 2009;PEREIRA et al., 2013).

Most of $\mathrm{HCV}$ patients presented up to 8 years of schooling and received until US\$620.00 monthly income showing low socioeconomic status. Usually, individuals at low socioeconomic status lived in poor conditions in small houses. In this situation, sharing personal hygiene items like toothbrushes or razor blades is common what could increase the risk of intrafamiliar transmission of HCV (CAVALHEIRO et al., 2009).

Most of HCV patients did not report condom use in the last intercourse what could increase $\mathrm{HCV}$ acquisition. $\mathrm{HCV}$ transmission by sexual contact differs by the type of sexual relationship. Persons in long-term monogamous partnerships are at lower risk of $\mathrm{HCV}$ acquisition ( $0 \%$ to $0.6 \%$ per year) than persons with multiple partners or those at risk for sexually transmitted diseases $(0.4 \%$ to $1.8 \%$ per year). Although sexual transmission of $\mathrm{HCV}$ is not well established, it is suggested to intensify the campaigns that encourage condom use aiming the prevention of sexually transmitted diseases (TERRAULT, 2002).

$\mathrm{HCV}$ genotype 2 was the most prevalent in this study what it was not observed in studies conducted in other regions of Brazil (VIEIRA et al., 2011; PEREIRA et al., 2013; PERONE et al., 2008). This result may be related to mode of HCV transmission (PUTZEYS et al.,2011); characteristics of the studied population, among them the fact that half of population is composed of immigrants from many states of the country; type of method used for genotyping or due to the number of samples that were not genotyped in the study. Further investigations should be conducted in order to investigate this finding.

This study presents some limitations. The cross sectional design of this study does not allow the establishment of direct causal relationships or 
the temporal sequence between the variables investigated and $\mathrm{HCV}$ infection. However, these cross-sectional population-based studies are useful tools for public health planning, understanding disease etiology and hypothesis generation. Furthermore, the convenience characteristic of this sample that did not allow to investigate some important risk factors, like blood transfusion or tattooing history or to determine $\mathrm{HCV}$ genotype from all samples. Nevertheless, considering the scarcity of epidemiological data about $\mathrm{HCV}$ infection in this region, the results of the present study could be helpful to increase preventive measures among such specific groups, like males and individuals from low socioeconomic status.

In conclusion, $\mathrm{HCV}$ infected individuals from Uberlandia city presented low socioeconomic level indicating the necessity of education campaigns in this population in order to increase the knowledge about risk factors, prevention and treatment of $\mathrm{HCV}$.

\section{CONFLICT OF INTEREST}

The authors declare that there is no conflict of interest.

\section{AGRADECIMENTOS}

Os autores gostariam de agradecer ao hospital de Clínicas da Universidade Federal de Uberlândia, Minas Gerais, por garantir o acesso às informações sobre os pacientes com hepatite $\mathrm{C}$.

Este estudo foi financiado pela Coordenação de Aperfeiçoamento de Pessoal de Nível Superior (CAPES) e pelo Conselho Nacional de Desenvolvimento Científico e Tecnológico (CNPQ).

RESUMO: O vírus da hepatite C (HCV) é um sério problema de saúde pública e a principal causa de transplante de fígado devido à cirrose e carcinoma hepatocelular. No Brasil, estima-se que há aproximadamente 2 a 3 milhões de portadores crônicos do HCV. Poucos dados sobre a infecção pelo HCV na região oeste do estado de Minas Gerais estão disponíveis. Devido à ausência de vacina eficaz contra esse importante patógeno humano e aos altos custos do tratamento antiviral, é importante realizar estudos epidemiológicos com a finalidade de executar o planejamento e implementação de medidas para prevenir a hepatite $\mathrm{C}$ em diferentes populações. Portanto, o objetivo deste estudo é descrever os aspectos epidemiológicos dos pacientes portadores de HCV da região oeste do estado de Minas Gerais, Brasil. Dados sociodemográficos e fatores de risco para a infecção com HCV foram determinados de 74 pacientes portadores de HCV da cidade de Uberlândia, Minas Gerais. Amostras de soro reativas foram submetidas às detecções de HCV RNA e genótipo. A maioria dos indivíduos eram homens $(63,5 \%)$ com média de idade de 51 anos e baixo nível socioeconômico. O genótipo do $\mathrm{HCV}$ foi determinado entre 40 amostras e as frequências foram: genótipo 2 (45\%), 1 $(37,5 \%)$ e $3(17,5 \%)$. A infecção com o vírus da hepatite $\mathrm{C}$ foi frequente entre homens e indivíduos de baixo nível socioeconômico.

PALAVRAS-CHAVE: Hepatite C. Epidemiologia. Saúde Pública.

\section{REFERENCES}

BRAZIL. Ministry of Health. Epidemiological Bulletin on Viral Hepatitis. Brasília, Brazil: Health Surveillance Secretariat, Department of STD, AIDS and Viral Hepatitis, Ministry of Health; 2011 (Portuguese).

http://www.aids.gov.br/sites/default/files/anexos/publicacao/2011/50073/

boletim_hepatites2011_pdf_64874.pdf

CAVALHEIRO, N. P.; ROSA, A. DE L. A.; SLAVA, E.; TENGAN, F. M.; ARAÚJO, E. S.; BARONE A. A. Hepatitis C: sexual or intrafamilial transmission? Epidemiological and phylogenetic analysis of hepatitis $C$ virus in 24 infected couples. Rev. Soc. Bras. Med. Trop., Uberaba, v. 42, n. 3, p. 239-244, jun. 2009.

GARCIA, F. B.; PEREIRA G. A.; MARTINS, P. R. J.; MORAES-SOUZA, H. Epidemiological profile of hepatitis $\mathrm{C}$ in blood donors at the Uberaba Regional Blood Center. Rev. Soc. Bras. Med. Trop., Uberaba, v. 42, p. 1-4, jan./fev., 2009. 
KRETZER, I. F.; LIVRAMENTO, A.; CUNHA, J.; GONÇALVES, S.; TOSIN, I.; SPADA, C.; TREITINGER A. Hepatitis $\mathrm{C}$ worldwide and in Brazil: silent epidemic--data on disease including incidence, transmission, prevention, and treatment. Scientific World Journal, New York, v. 2014, p. 1-10, jun. 2014. http://dx.doi.org/10.1155/2014/827849

LAVANCHY, D. Evolving epidemiology of hepatitis C virus. Clin Microbiol Infect, France, v. 17, n. 2, p. 107-115, feb. 2011. http://dx.doi.org/10.1111/j.1469-0691.2010.03432.x

PEREIRA, L. M.; MARTELLI, C. M.; MOREIRA, R. C.; MERCHAN-HAMMAN, E.; STEIN, A. T.; CARDOSO, M. R.; FIGUEIREDO, G. M.; MONTARROYOS, U. R.; BRAGA, C; TURCHI, M. D.; CORAL, G.; CRESPO, D.; LIMA, M. L.; ALENCAR, L. C.; COSTA, M.; DOS SANTOS, A. A.; XIMENES, R. A. Prevalence and risk factors of Hepatitis C virus infection in Brazil, 2005 through 2009: a cross-sectional study. BMC Infect Dis, England, v. 13, p. 1-12, feb. 2013.

PERONE, C.; DEL CASTILlO, D. M.; PEREIRA, G. L.; CARVALHO, N. O; JANUÁRIO, J. N.; TEIXEIRA, R. Alta prevalência do genótipo 1 em portadores de hepatite C crônica em Belo Horizonte, MG. Rev. Soc. Bras. Med. Trop., Uberaba , v. 41, n. 3, p. 238-242 jun. 2008.

PUTZEYS, V.; GÉRARD, C.; BASTENS, B.; WAIN, E.; BATAILLE, C.; DEFRANCE, P.; BELAICHE, J.; DELWAIDE, J.; BELAICHE, J.; DELWAIDE, J.; DE ROOVER, A.; DETRY, O.; GÉRARD, C.; HONORÉ P.; MAGGIPINTO G.; RENTIER B.; VAIRA D; Groupe Liégeois d'Etude des Virus Hépatotropes. Hepatitis C of genotype 2: the role of medical invasive exams. Acta Gastroenterol Belg, Belgium, v. 74, n. 2, p. 277-80, jun. 2011.

SMITH, D. B.; BUKH, J.; KUIKEN, C.; MUERHOFF, A. S.; RICE, C. M.; STAPLETON, J. T.; SIMMONDS, P. Expanded classification of hepatitis $C$ virus into 7 genotypes and 67 subtypes: Updated criteria and genotype assignment web resource. Hepatology, United States, v. 59, n. 1, p. 318-327, jan. 2014.

http://dx.doi.org/10.1002/hep.26744

TERRAULT, N. A. Sexual activity as a risk factor for hepatitis C. Hepatology, United States, v. 36, p. 99-105, nov. 2002. http://dx.doi.org/10.1053/jhep.2002.36797 http://dx.doi.org/10.1002/hep.1840360713

VIEIRA D. S.; ALVARADO-MORA M. V.; BOTELHO L.; CARRILHO F. J.; PINHO J. R.; SALCEDO J.M. Distribution of hepatitis c virus (hcv) genotypes in patients with chronic infection from Rondônia, Brazil. Virol J, England, v. 8, 165, apr. 2011

XIMENES, R. A. A.; PEREIRA, L. M. B.; MARTELLI, C. M. T.; MERCHÁN-HAMANN, EDGAR.; STEIN, A. T.; FIGUEIREDO, G. M.; BRAGA, M. C.; MONTARROYOS, U. R.; BRASIL, L. M.; TURCHI, M. D.; FONSECA, J. C. F.; LIMA, M. L. C.; ALENCAR, L. C. A.; COSTA, M.; CORAL, G.; MOREIRA, R. C.; CARDOSO, M. R. A. Methodology of a nationwide cross-sectional survey of prevalence and epidemiological patterns of hepatitis A, B and C infection in Brazil. Cad. Saúde Pública, Rio de Janeiro, v. 26, n. 9, p. 16931704, sept. 2010. 